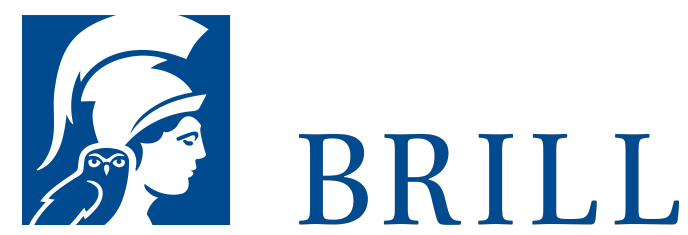

\title{
Knots und Vortices
}

T. S. Eliots und Ezra Pounds Dichtungstheorie zwischen Tradition und Innovation

Author: Stefan Plasa

Plasas Studie untersucht die Modernistische Dichtungstheorie Eliots und Pounds im Umfeld der großen Umbrüche in Kunst und Kultur der Jahrzehnte um 1900 Die zahlreichen Bezüge Eliots und Pounds zu den weltliterarischen und geistigen Traditionen werden ebenso in den Blick genommen wie ihre äußerst ploblematischen kulturkritischen Ansätze zur Begründung eines neuen, differenzierten ModerneVerständnisses sowie die damit eng verknüpften Aspekte einer möglichts "objektiven" und "entpersönlichten" Dichtung.

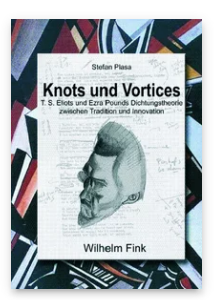

Pages: 649

Seiten

Language:

German

Subjects:

English \&

Anglophone,

Literature and

Cultural Studies

Publisher: Brill |

Fink

E-Book (PDF)

Released online:

16 Dec 2019

ISBN: 978-3-

8467-4857-2

List price

USD $\$ 54.00$

Paperback

Publication date:

og Dec 2009

ISBN: $978-3-$

7705-4857-6

List price

USD $\$ 54.00$ 
For more information see brill.com

Order information: Order online at brill.com +44330 333 0049 | customerservices@brill.com Submission information: brill.com/authors

Titles published by Brill | Fink, Brill | mentis or Brill | Schöningh: +49(o)715413279216| brill@brocom.de 